\title{
Telomerase Protein Component 1
}

National Cancer Institute

\section{Source}

National Cancer Institute. Telomerase Protein Component 1. NCI Thesaurus. Code C20074.

Telomerase protein component 1 (2627 aa, $290 \mathrm{kDa}$ ) is encoded by the human TEP1 gene. This protein plays a role in telomerase activity and formation of the vault riboprotein particle. 